\title{
Occurence of the Australian cladoceran Armatalona macrocopa (Sars, 1894) (Cladocera: Anomopoda: Chydoridae) in Thailand
}

\author{
Artem Yu. Sinev ${ }^{1}$, Sawitri Nachai ${ }^{2}$ and La-orsri Sanoamuang ${ }^{2}$ \\ ${ }^{1}$ Department of Invertebrate Zoology, Biological Faculty, Moscow State University, Vorob'evy \\ Gory, Moscow 119992 Russia. \\ e-mail:artem_sinev@mail.ru \\ ${ }^{2}$ Applied Taxonomic Research Center, Department of Biology, Faculty of Science, Khon Kaen \\ University, Khon Kaen 40002, Thailand. \\ e-mail: la_orsri@kku.ac.th
}

ABSTRACT: A chydorid cladoceran, Armatalona macrocopa (Sars, 1894) known from Australia and New Zealand, was found in North-East Thailand. This is a new record for Thailand and for the Asian fauna. Morphology of the specimens from Thailand and distribution of the genus Armatalona Sinev, 2004 are discussed.

KEYWORDS: cladocera, Thailand, Armatalona macrocopa, new record.

\section{Находка австралийского ветвистоусого ракообразного Armatalona macrocopa (Sars, 1894) (Cladocera: Anomopoda: Chydoridae) в Таиланде}

\author{
А. Ю. Синев ${ }^{1}$, С. Начаи르 и Л. Саноамуанг ${ }^{2}$ \\ ${ }^{1}$ Кафедра зоологии беспозвоночных, Биологический факультет, Московский Государствен- \\ ный Университет им. М. В. Ломоносова, Воробьевы горы, Москва 119992, Россия. \\ e-mail: artem_sinev@mail.ru \\ ${ }^{2}$ Applied Taxonomic Research Center, Department of Biology, Faculty of Science, Khon Kaen \\ University, Khon Kaen 40002, Thailand. \\ e-mail: la_orsri@kku.ac.th
}

РЕЗЮМЕ: Ветвистоусый рачок семейства Chydoridae Armatalona macrocopa (Sars, 1894), ранее известный с территории Австралии и Новой Зеландии, был обнаружен в Северо-Восточном Таиланде. Это первая находка вида для Таиланда и для азиатской фауны в целом. Обсуждается морфология найденных особей и распространение рода Armatalona Sinev, 2004.

КЛЮЧЕВЫЕ СЛОВА: ветвистоусые ракообразные, Таиланд,Armatalona macrocopa, новое местонахождение. 


\section{Introduction}

Recent studies of the cladocerans from Thailand (Sanoamuang, 1998a; Saeng-aroon, Sanoamuang, 2002; Kotov, Sanuamuang, 2004b; Sanoamuang, Faitakum, 2005; Maiphae et al, 2005) significantly improved the knowledge of the region's fauna, taxonomic status of several species was clarified, and several new species were found (Kotov, Sanuamuang, 2004a; Kotov et al., 2004; Kotov et al., 2005).Armatalona macrocopa (Sars, 1894) was found in NorthEast Thailand. This is the first record of genus Armatalona Sinev, 2004, in Asia.

\section{Material and methods}

Studied material includes 16 parthenogenetic females from Bueng Khong Long Lake, Nong Khai Province, Thailand, 22.06.2002 and 3 parthenogenetic females from a temporary pond in Arkas subdistrict, Srisongkhram district, Nakhophanom Province, Thailand, 07.02.2005. Specimens were selected from samples under a binocular stereoscopic microscope, placed on slides (in a drop of a glycerol), viewed under an optical microscope(Olympus BX51) and photographed with an Olympus DP12 digital camera. All specimens were measured using an eyepiece-micrometer. Drawings were made with a camera lucida.

Armatalona macrocopa (Sars, 1894)

Alona macrocopa Sars, 1894: 20-23, P1. III, fig. 11-15; Gurney, 1927 : 75-76, fig. 10; Smirnov, 1989: 139, fig. 3; Alona abbreviata Sars, 1895: 40-42, P1. 6, fig. 5-6; Gurney, 1927: 76.

Alonella duodonta Henry, 1922: 49, text-figures 1-4. Biapertura macrocopa Smirnov et Timms, 1983: 6263, fig. $73-74$.

Alona gurneyi Smirnov, 2001: 3.

Armatalona macrocopa: Sinev, 2004 37-40, fig. 1-50.

Studied specimens (Figs. 1A; 2A, F) agree well with the diagnosis of the species (see Sinev, 2004), and demonstrate all diagnostic features of A. macrocopa - ovoid Alonella-like body (Fig. 1B), two major head pores (Fig. 1D), spine-like setae on basal and middle segments of the endopod of antenna II (Figs. 1F; 2E), strongly differentiated in size and thickness apical setae of the endopod of antenna II, postabdomen of characteristic shape and armature (Figs. 1C; 2B, G). Specimens from Arkas subdistrict have valves with sculpture in shape of longitudinal striae only, several specimens from Bueng Khong Long Lake have tuberculated valves (both types of sculpture are present in Australian and New Zealand populations (Sinev, 2004)). Specimens from both localities lack denticles on the posteroventral angle of the valves (Fig. 2D). Labral plate of most specimens lack denticles on the anterior margin; the two largest specimen from Bueng Khong Long Lake have a single denticle. Length of adult parthenogenetic females was $0.32-0.37 \mathrm{~mm}$, height $0.21-0.26 \mathrm{~mm}$. There is no significant difference in size with Australian specimens.

Specimens from Thailand differ from those in Australian and New Zealand populations (as described by Sinev, 2004) in two characters. They have lateral fascicles on the postanal part of the postabdomen consisting of 4-7 thin setules instead of 2-4 thick ones. The smallest apical seta of the antennal endopod is shorter in Thai specimens, not reaching the joint of the medium seta, while in Australian specimens it reaches to the middle of the distal part of this seta.

\section{Discussion}

The genus Armatalona contains two species, A. macrocopa and A. imitatoria (Smirnov, 1989), initially described as members of the genus Alona. The former species was known from New Zealand and Australia (including Western Australia), the latter from Australia only. Both species are relatively common in Australia. According to Sinev (2004), Armatalona separated early from the bulk of the Aloninae, with possible close affinities only to another Australian endemic genus, Pseudomonospilus Smirnov, 2001.

This is not the first record of Australian freshwater invertebrates from Thailand. Five Rotifera species, previously presumed to be 


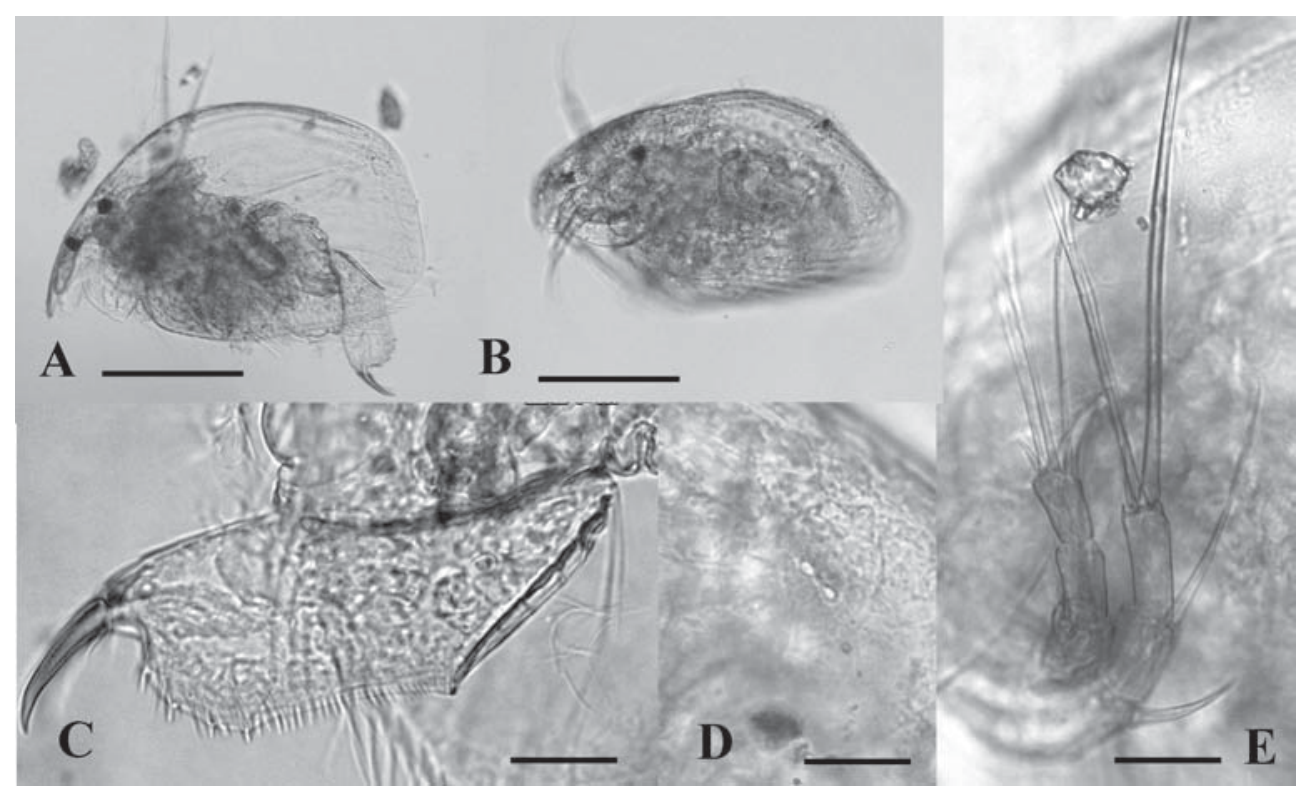

Fig. 1. Armatalona macrocopa (Sars, 1894), adult parthenogenetic females from a temporary pond in Arkas subdistrict, Srisongkhram district, Nakhophanom Province, Thailand.

A - lateral view, B - dorso-lateral view, C - postabdomen, D - head pores, E - antenna II. Scale bars denote 0.1 $\mathrm{mm}$ for $\mathrm{A}-\mathrm{B}, 0.02 \mathrm{~mm}$ for $\mathrm{C}-\mathrm{E}$.

Рис. 1. Armatalona macrocopa (Sars, 1894), взрослая партеногенетическая самка из временного водоема, Arkas subdistrict, Srisongkhram district, Nakhophanom Province, Таиланд.

А - вид сбоку, В - вид со спины, С - постабдомен, D — головные поры, Е - антенна II. Масштаб 0,1 мм для A-B, 0,02 мм для C-E.

Australian endemics, were found there (Sanoamuang et al. 1995; Sanoamuang, 1998b). However,all other species of Cladocera common for Thailand and Australia, like Karualona karua (King, 1853), Leberis diaphanus (King, 1853), or Alona verrucosa Sars, 1901 are widely distributed species, with most of them found in all tropical regions of the Old World.

Morphological differences between Australian and Thai populations of A. macrocopa suggest that the Thai population had been separated from Australian populations for a significant time. It seems that A. macrocopa is a native species for the Thai fauna, not a recent invader. Of course, it should be noted that cladoceran fauna of New Guinea and Indonesia is poorly studied, and there is a possibility that $A$. macrocopa inhabits this region, and has a continuous distribution from Australasia to New Zealand.

\section{Acknowledgements}

This work was supported by the TRF/BIOTEC Special Program for Biodiversity Research, Training grant BRT T_145023, and by a grant from the Russian Foundation for Basic Research (06-04-48624) for the first author. The first author would like to thank the Applied Taxonomic Research Center, Khon Kaen University for financial support for his short visit in 2006. We thank Jittra Teeramaethee for her help in collecting specimens.

\section{References}

Kotov A.A., Maiphae S., Sanoamuang L. 2005. Revision of Macrotrix paulensis - like species in Asia, and phylogeny of paulensis-group // Archiv fuer Hydrobiologie, Supplement Band 151/3, Monographic Studies. P.269-299. 


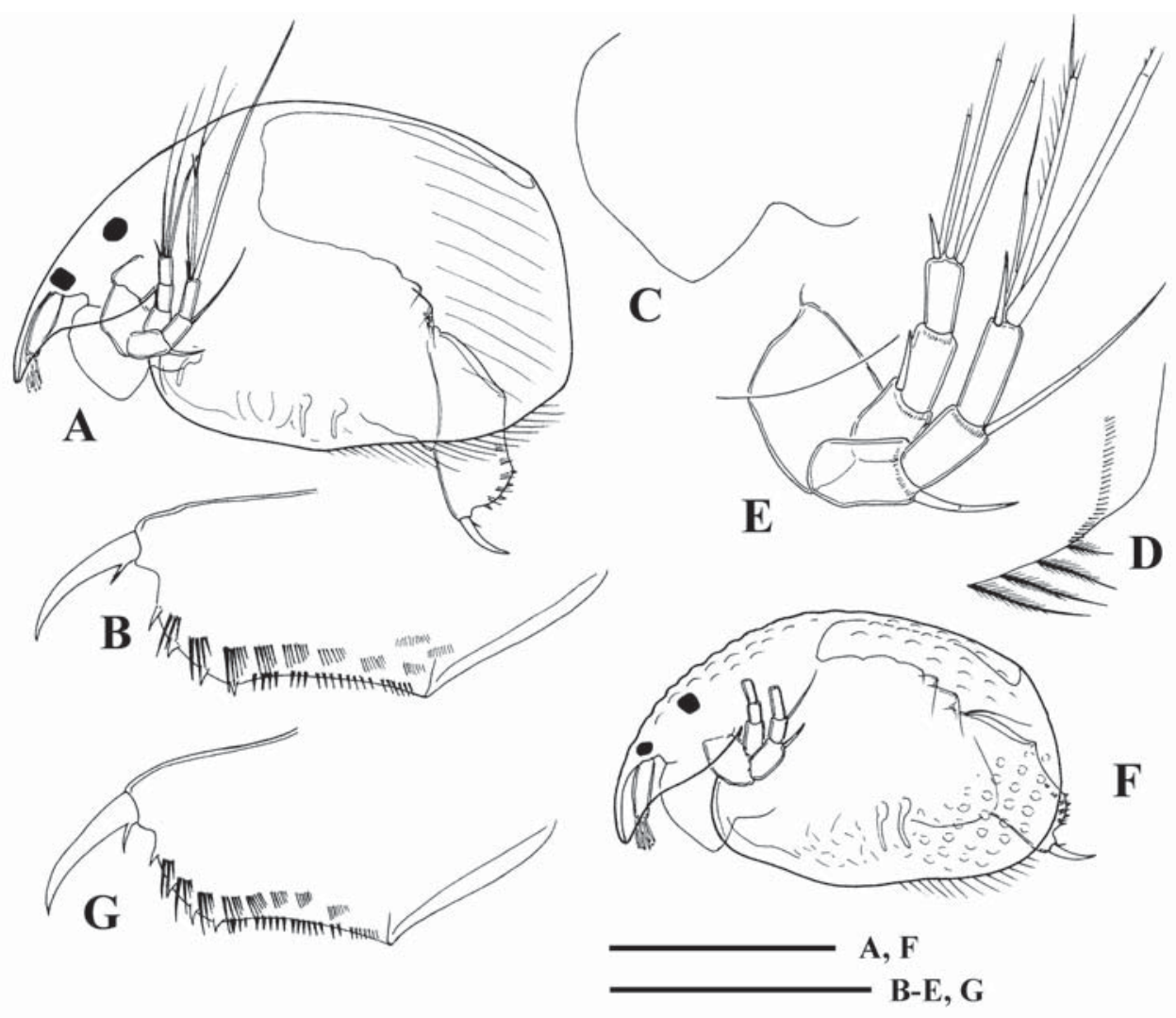

Fig. 2. Armatalona macrocopa (Sars, 1894) from Thailand.

A-E - adult parthenogenetic female from a temporary pond in Arkas subdistrict, Srisongkhram district, Nakhophanom Province. A - lateral view, B - postabdomen, C - labrum, D - posteroventral angle of valves, E - antenna II; FG - juvenile female of instar II from Bueng Khong Long lake, Nong Khai Province: F - lateral view, G — postabdomen. Scale bars denote $0.1 \mathrm{~mm}$ for A, F, $0.05 \mathrm{~mm}$ for D-E, G.

Рис. 2. Armatalona macrocopa (Sars, 1894) из Таиланда.

A-E - взрослая партеногенетическая самка из временного водоема Arkas subdistrict, Srisongkhram district, Nakhophanom Province. A — вид сбоку, В — постабдомен, C — лябрум, D — заднее-нижний угол створок, E антенна II; F-G - ювенильная самка первого возраста из озера Bueng Khong Long, Nong Khai Province. F — вид сбоку, G - постабдомен. Масштаб 0,1 мм для A, F, 0,05 мм для D-E, G.

Kotov A.A., Sanoamuang L. 2004a. Ilyocryptus thailandensis sp. n. (Cladocera: Anomopoda: Ilyocryptidae) from North Thailand. // International Revue of Hydrobiology. Vol.89. No.2. P.206-214.

Kotov A.A., Sanoamuang L. 2004b. Comments on morphology of Nicsmirnovius eximius (Kiser, 1948) (Aloninae, Anomopoda, Cladocera) in Thailand, with description of its male. // Hydrobiologia. Vol.519. P.117-125.

Kotov A.A., Štifter P., Sanoamuang L. 2005. Notes on the genus Ilyuocryptus Sars, 1862 (Cladocera: Anomopoda: Ilyocryptidae). 8. Ilyocryptus isanensis $\mathrm{sp}$. n. from North-East Thailand // Arthropoda Selecta. Vol.14. No.3. P.229-239.
Maiphae S., Pholpuntin P., Dumont H.J. 2005. Species richness of the Cladocera (Branchiopoda: Anomopoda and Ctenopoda) in southern Thailand, and its complementarity with neighboring regions // Hydrobiologia. Vol.537. P.147-156.

Saeng-aroon C., Sanoamuang L. 2002. Species diversity and abundance of Cladocera in Lake Kud-Thing, Nong Khai Province // Khon Kaen University Research Journal. Vol.7. P.14-25 [in Thai].

Sanoamuang L. 1998a. Contributions to the knowledge of the Cladocera of north-east Thailand // Hydrobiologia. Vol.362. P.45-53. 
Sanoamuang L. 1998b. Rotifera of some freshwater habitats in the floodplain of the River Nan, northern Thailand // Hydrobiologia. Vol.387-388. P.27-33.

Sanoamuang L., Faitakum S. 2005. Species diversity of cladocerans and copepods in the floodplain of the River Mun, Northeast Thailand // Khon Kaen University Research Journal. Vol.10. P.106-113 [in Thai].
Sanoamuang L., Segers H., Dumont H.J. 1995. Additions to the rotifer fauna of south-east Asia: new and rare species from north-east Thailand // Hydrobiologia. Vol.313-314. P.35-45.

Sinev A.Y. 2004. Armatalona gen. n. - a new genus of subfamily Aloninae (Anomopoda, Chydoridae), separated from genus Alona Baird, 1840 // Hydrobiologia. Vol.520. P.29-47.

Accepted April 20, 2007

Published online May 25, 2007 